\title{
ZAUM (BEYONSENSE, EDUCANTO) IN THE KOMI TRADITION OF INCANTATIONS: REVISITING THE ISSUE OF ORIGINS
}

\author{
Anatoly Panyukov \\ Leading Research Fellow \\ Folklore Archive, Institute of Language, Literature, and History \\ Komi Science Centre, Russian Academy of Sciences, Russia \\ Email:apankomisc@mail.ru
}

\begin{abstract}
In order to provide a general overview of particular aspects of the topic in the title of this article, the author suggests having a look at one specific example from the Komi tradition of incantations. In the analytical part of the article, the author makes a hypothesis: Linguistic transformations verified as zaum (beyonsense, educanto) can occur as a result of compression of a source text (pretext, prototext) into a rhythmical matrix of the act of incantation. By the rhythmical matrix we mean a complex fixed structure of rhythmical subsystems: sound-rhythmical, rhythmo-melodic, metrical-rhythmical, and other dimensions. The compression of the prototext into the text of an incantation can have a non-linear character and be the result of a peculiar strategy of the transfer of knowledge pertaining to incantations from a teacher to a student. By virtue of a number of specific psychophysiological attitudes and limitations, the student does not remember the text of the incantation, but reproduces some deeper levels of the magical and ritual performative related to the rhythmical matrix. And it is into the matrix reproduced by his or her consciousness that a new verbal stream made up of the components of the source text, fixed in the short-term memory of the student, is incorporated.
\end{abstract}

Keywords: borrowings, folklore, incantation zaum, Komi-Zyrians, rhythm, rhythmical matrix, structure

\section{INTRODUCTION}

Folklore zaum is a phenomenon that is versatile and multi-faceted both in its origin and functions (which serve a wide range of ritual, magical, and game forms of communication with the 'other' world), and in the degree of being distant from the natural language (both in phonetic terms, i.e. 'pure nonsense', when the sounds do not add up into morphemes, and in the suprasyntactic sense, when, 
even though the formal and grammatically correct language structures are used, it is still fundamentally unclear what the text refers to) (Janecek 1996).

The interrelation of all kinds of zaum with the mother tongue of the carrier, which is generally recognized today (any kind of zaum is the actualization of the linguistic and cultural dominating idea) assumes the search for meanings, engrained in it, on the fringes of the standard language, within the realm of sound-semantic associations that are relevant for the performer/listener (Shlyakhova 2006). The subjective factor, the predominance of the emotional and intuitive origins in terms of perception of zaum determines the probabilistic nature of textual research. However, it does not deny us the opportunity to speak about certain formal and conceptual rules of organizing zaum texts (Panyukov 2010). The approaches to the interpretation of poetic zaum that currently prevail assume the search for the semantics of the texts through semantic 'translation' of detectable implications: intralinguistic, foreign, pertaining to a foreign culture. The most radical analysts have put forward the opinion of the fundamental semantic openness, i.e., the decipherability of zaum (Davydov 2007: 66).

With regard to the Komi tradition of incantations, the pathos of the avenues for interpretation is mainly held back by the blurriness of the borders of the linguistic mode itself, which is determined as zaum. If we approach it from the perspective of distancing ourselves from the dominant linguistic structure, we will see that there are linguistic 'shifts' that can be qualified as zaum in almost every single incantation text. First of all, it is related to the abundance of Russian-language components that take on a different underlying rationale in the monolingual environment and are not simply incorporated into the repertoire, but also into a poetic armoury of the tradition (in the form of text-building elements with ambiguous semantics - quasi morphemes, quasi words, quasi syntactic structures of different levels of complexity). In addition to that, the 'internal' specific character of this genre contributes to the semantic ambiguity of the texts of incantations. In an extended sense, the word нилкььв 'incantation' means a combination of the means of word-magical impact on nature, which are different in the means of organization of verbal text (Ulyashev 1999). The incantations - нимкыь - get their specific ellipsoid structure, which requires the context of knowledge, from the nominative mode of text-building that is concept-based and correlates with the literal meaning of this term (ним 'name' $+\kappa ы є$ 'word, language'), while нимкыв represents a certain combination of key words or consists of one word only (Ulyashev 1999). Hence a number of topical issues arise when enunciating the topic of zaum (beyonsense, educanto) in the Komi tradition of incantations itself, which are related both to the origins of certain phenomena of zaum and their existence. In order to specify the gist of the problem, let us have a look at the text of a borrowed incantation which is representative of the current state of the tradition. 


\section{ZAUM IN A BORROWED INCANTATORY TEXT}

On the basis of the submitted analytical calculations I will analyse the incantation text which is alien, i.e. in Russian. This incantation is related to traditional magical and medical practice, but there is only a written fraction of the act of incantation in my possession.

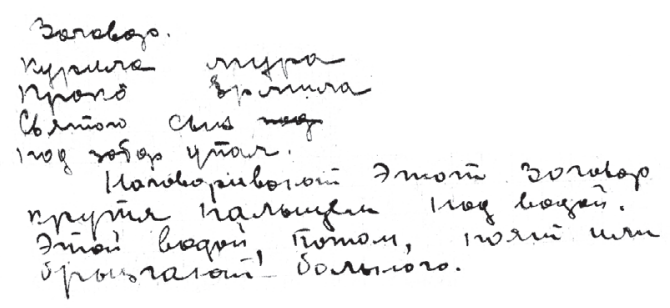

Курила мура

Прокӧ Ерлила

Святого сын

Под забор упал.

This incantation is said while swirling a finger under water. Then a sick person is washed or splashed with this water. ${ }^{1}$

According to the data in the archives, this incantation was recorded by a student of Syktyvkar Pedagogical College during folklore fieldwork in June 1935. Unfortunately, the collector did not record the passport data of the reciter, but, proceeding from some other records, we can assume that this text could have been recorded in Grivensky village soviet, Koygorodsky District, the Komi Republic. However, in terms of its linguistic characteristics, it may be said that, regardless of its obvious characteristics referring to the Russian language, it was recorded from someone speaking the Komi language.

\section{Textual aspect}

First of all, let us have a closer look at the actional level. According to the actions that accompany the incantation process, this is an adaptation of the tradition of the magical evil-eye treatment which is widespread in the Komi tradition - вомидз, in which splashing with charmed water and giving it to drink can complement each other. For example, in the methods of treatment of волидз, which were described in detail by Sidorov, after being splashed with charmed water, a sick person was given this water to drink, 'so that the disease would not rush into the intestines'; besides, sometimes a 'shower' was given to a sick person using charmed water: to do that, a sieve was set up above the stove (cëp), and water was poured through it right on the sick person sitting under the sieve (Sidorov 1997 [1928]: 159). However, in this case, we are dealing with a simplified version of preparing charmed water, which does not require any special conditions or attributes (a strong connection with a specific time 
of day or place, crossing water with a knife, using stones, pouring the water through stones or a door handle, etc.). Perhaps we are seeing here a 'mobile' adaptation, which developed occasionally, i.e., the one that can be easily reproduced in any conditions of treatment, and no parallels have yet been found to it in any other traditions. Nevertheless, it is this kind of adaptation that is unusual for the incantation tradition that has the 'primary motivation' of some kind - it is a whirlpool. In the cultures of many different peoples, water taken from a whirlpool is attributed with magical features (see Vinogradova 2002: 35 about the Slavic traditions). The Komi-Zyrians entrusted sand taken from a whirlpool with magical features, too:

The sand that is taken from the whirlpool in the river has the special quality of exterminating bedbugs in living quarters. In all likelihood the belief is based on the fact that in the whirlpool the sand whirls and makes circles, which makes it magical. (Sidorov 1997: 211)

Proceeding from the fact that this text is in the Russian language which became deformed as a result of entering a foreign linguistic environment, let us 'read' it according to the rules of the Russian prosody:

$$
\begin{aligned}
& \text { КУРиЛА МуРА } \\
& \text { ПРоКӦ ЕРМиЛА } \\
& \text { СВЯТоГО СьН } \\
& \text { ПоД ЗАБоР УПаЛ. }
\end{aligned}
$$

The text consists of two parts (microtexts) that are different from each other both in formal and semantic features.

Microtext 1 is a clearly deformed fragment of the Russian text with the component ПРоКӦ from the Komi language, which is probably the local form of the name Procopius. Correspondingly, the line Прокӧ Ерлила could be interpreted either as a local form of the full name Yermil Prokopyevich or as a list of names (there are no punctuation marks in the manuscript). Additionally, in morphological terms, the word ерлила is similar to the word курила, and we should not rule out the possibility of verbal apprehension here.

Microtext 2 is a grammatically correct sentence in the Russian language СВЯТоГО СыН ПоД ЗАБоР УПаЛ.

At first glance, microtext 2 really looks like a quote from the Russian text (a prototext) that has been divorced from its context. However, it is sufficient to know the Russian incantation tradition in very broad terms in order to see the apparent foreignness of this quote. While the image of the Holy Son could fit in the system of incantation characters (provided that the functions that correspond to sacral characters exist), the motive of a sacral character falling 
off the fence contradicts the incantation image of the world, and at best, it could be interpreted as a mockery of tradition.

Such a reconstruction of the prototext becomes even more absurd if the lexical content of microtext 1 is interpreted in a similar way. If we consider (in the same line with ПРоКӦ ЕРМиЛА 'Yermil Prokopyevich' / 'Procopius, Yermil') the word $M y P A$ as an anthroponym or a personym, and the word $К У P u Л A$ as a Russian verb (thus restricting the degree of beyonsense with the syntactic level: a syntactically correct structure of word groups that does not have a coherent meaning), the motif of a sacral character falling off a fence could be subjoined with the motif of the character named Mura who was smoking / enveloping with smoke someone named Prokö Yermil / Procopius, Yermil, or the character named Mura was smoking / enveloping with smoke, and the character named Prokö yermila. The scenario that we are getting falls into place and makes a specific 'plot', but it is obvious that further searching in this particular textological direction would not lead us to the protosources we are looking for.

This is why we should go back to where we started and consider this text from the perspective of the dominant language, i.e., the Komi language. Since the lexical content clearly contradicts it, I will pay closer attention to the structural characteristics of the text and find the most generalized and conceptually feasible way to approach the topic of the Komi tradition of incantations. Let us list the points of reference once again:

- We have the text of an incantation that was recorded from a Komi speaker and existed in the Komi tradition;

- In spite of the fact that the magical act itself is incomplete, the text of the incantation was recorded in full, and, most likely, it was used within the tradition in the same form we can see it now;

- In its lexical and syntactic structure, the text is aimed at the Russianspeaking environment, and, with great probability, it originates from a prototext (or prototexts) in Russian, while its genre distinctness is unknown to us; - Correspondingly, we have a text with inexplicit semantics, which assumes the search for meanings engrained in it on the fringes of standard language.

\section{Phono-semantic aspect}

Let us proceed from the fact that this is the text of incantation that existed in the Komi tradition. The trend of stressing the first syllable in words, observed in the Komi language, had an impact on the old borrowings from the Russian language, too, and in this particular case, such borrowings are КуРИТНЫ 'to smoke', and СЬВаТӦЙ 'sacred, holy' (although here we can also draw on the 
Church Slavonic word СВяТЫЙ). Using the first line of the text as a template (it gives a specific syllabic and rhythmical pattern), we can try to reconstruct the prosodic image, or, in terms of rhythmics, the lexical rhythm ${ }^{2}$ of this incantation. We must pause to say that we do not touch upon pitch specifications of stress: in the Komi-Zyrian language, the stress is tonic, and it is different from expiratory and longitudinal stress in Russian, and the symbol 'v', as a matter of fact, means not so much the stress as toning up.

As a result of such a reconstruction, we get an almost perfect dactylic dimeter with a pyrrhic that marks the endings of the lines:

$$
\begin{aligned}
& \text { КуРИЛА МуРА } \\
& \text { ПРоКӦ ЕРМиЛА } \\
& \text { СВяТОГО СъН } \\
& \text { ПоД ЗАБОР уПАЛ }
\end{aligned}
$$

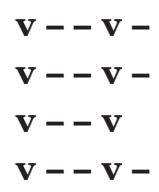

In addition to the only inaccuracy with cadency in the third line (one unstressed syllable is missing), we have one morphological inconsistency with the Russian language (if we draw on the thesis concerning the existence of the prototext in Russian), which can be explained as follows: ПоД-ЗАБОР is the acceptable clitic in the Russian speech (a preposition is merged with the next word); formally, the substantiated transfer of the stress in the word $y \Pi А Л(<У \Pi а Л)$ is consistent with the rhythmical structure. Here we should pay attention to an orthographic 'holdback' the collector experienced: at first, the preposition nод was written in the same line with the preceding expression святого сын, but then it was crossed out. It confirms my suggestion about the existence of a prosodic shift, which could cause fallacy in the sound perception.

The validity of further interpretation in the same vein is supported by the fact that the reconstructed rhythmical structure allows certain parallels between the verbal and actional codes to be observed. If we correlate the rhythm with the action done while saying the incantation (swirling a finger in water), it would be logical to assume that every single foot corresponds to one finger twist; correspondingly, swirling a finger is an irregular impulsive motion (rhythm $3 / 4+2 / 4$, which concurs with the rhythm of the incantation. In other words, this rhythmical (metrical and rhythmical) structure of the incantation is best matched to the actional level.

Now let us have a look at the only inaccuracy with cadency in the third line (one unstressed syllable is missing) and try to interpret it:

$$
\mathbf{v}--\mathbf{v}
$$


If we make an attempt to restore the 'pure' metric pattern of microtext 2 , the most feasible option would be the following:

\section{СВяТОГО СыНА ПоД ЗАБОР УПАЛ}

$$
\begin{aligned}
& \mathbf{v}--\mathbf{v}- \\
& \mathbf{v}--\mathbf{v}-
\end{aligned}
$$

While being metrically correct, this adaptation is erroneous in terms of Russian grammar, since there is no case agreement. This is why we can assume that the omission of an unstressed syllable is the result of correcting microtext 1 to make it properly Russian. This correction could have been made later, in the course of existence of the incantation within the tradition and, perhaps, it is the result of interference of yet another linguistic consciousness, the carrier of which also knew Russian to a certain extent. There is also a chance that such a correction could have been made at the moment of recording the incantation, since for the student-collector, and, probably, also for its performer in 1935 this grammar inaccuracy was obvious and could be regarded as a speech error.

The 'incorrect' word group святого сына elicits strong associations with a commonly known prayer formula 'In the name of the Father, and the Son, and the Holy Spirit (Amen)'. In the incantatory practice of the Komi, this formula was very widespread, and it could be used both as an independent нилкьвincantation and as a part of some other verbal texts (I will have a look at some of them below); besides, it was common in parochial practice, too. However, it should be pointed out that the association that emerges between the image of the 'Holy Son' and the formula of the prayer is non-linear, i.e., the Holy Son is not a direct quote from the texts, but rather a concentrate of some kind, an evocative and semantic cross-section of that formula. In order to understand the underlying principle for such a concentration (= transformation), we can refer to the method of positional analysis of the text, which is based on the idea of the golden ratio as the optimality proportion (Moskalchuk 1998). This golden ratio proportion is matched by the harmonious centre of the text (hereinafter referred to as the $\mathrm{HC}$ ), which is determined by the coefficient of 0.618 from the whole. The extensive factual material proves that it is the position of the HC in the text that is culminative on semantic, intonational, rhythmical, and other levels of its organization (Moskalchuk 1998, 2003; Korbut 2005).

\section{ВО иМЯ ОТЦа И СыНА И СВЯТоГО ДуХА (АМиНЬ) > СВяТОГО $\mathrm{Cb} \mathrm{HA}$}

Since I am only interested in the position of the HC in the whole text, the procedure for determining its location is quite simple: I take the total number of elementary units in the text as 1 and determine the proportion point as 0.618 : 0.382. Proceeding from the fact that I am dealing with a borrowing, a phonetic 
word or a syllable can be used as an elementary unit for the purposes of the positional analysis, or as a minimum element of the syllabic-rhythmical structure.

After a number of simple calculations, it turns out that the $\mathrm{HC}$ of this 14 (16)-syllable (or 5 (6)-word) text (admitting the possibility of the omission of the word Amen in the formula) is between syllables 8 and 9 (or between the 3rd and the 4 th words), i.e., either on the second syllable of the word son or between the words son and Holy. Consequently, we can assume that, as a result of the transformation (compression) of a specific prayer formula (which is perceived by linguistic consciousness and, respectively, stands out syntagmatically in the original prototext of the incantation as a separate microtext), the final text still has a component that corresponds to the $\mathrm{HC}$ of the formula $<$ the Son and the Holy>. The inversion of the component <the Son and the Holy> into the Holy Son can be related to the principle of teleologicity of the 'assembly' of the textual structure of the incantation (from the end to the beginning).

Moreover, if we do the same positional analysis of the entire incantation under consideration, we will see that the $\mathrm{HC}$ of the entire text (19-syllable or eight-word) is consistent with the HC of the prayer formula and is also located between the words Holy and Son. Additionally, several other levels of the dimensioning of the text are converged at this point: the same $\mathrm{HC}$ will remain both on the level of metrics and strophics:

КуРИЛА МуРА
ПРоКӦ ЕРМиЛА
СВяТОГО * СъН
ПоД ЗАБОР УПАЛ

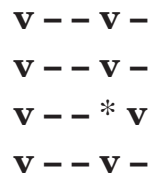

Thus, regardless of the semantic (lexical) incoherence, the incantation under consideration has a rigid structure and is harmonized. The component of the Holy Son, which lies at the heart of the HC, results from the non-linear transformation of the prayer formula, which was included in the prototext in Russian.

While the origins of the personym of the Holy Son in this incantation are more or less feasible, the motif of 'falling off the fence' looks even more absurd against such a prototextual background. This is why I will try to approach this motif from the same position of non-linearity, i.e., not to take it as a fragment of a prototext, but as an adaptation, or a compression of some prototexteme (the incantation formula, a paroemia, etc.).

So then, now we have a starting point that is reliable enough, i.e., the existence of a prayer formula in the prototext. By confining myself to the adaptations of the treatment of the evil eye that are available, I have taken notice of another borrowed incantation against волидз 'the evil eye': 
Спаса-Варука,

Причистая владька,

Железный стьн,

Медные ворота!

Отойдите от меня,

Отшатните от меня

Все нечистьье дуки

Все виды и все болезни. Сал Кристос "благослови Кристос"

Во имя отиа... Алинь.

(Sidorov 1997 [1928]: 163-164)

It is highly likely that this text was rewritten by Sidorov from the manuscript found in the village of Lopydino, on the banks of the Lokchim River (Middle Vychegda). We can see that this text also ends with the same final formula of 'In the name of...', and the incantation itself is a combination of typical guarding (protective) formulas. However, it clearly has the traces of specific perception of the semantic organization of a Russian incantation, whereby the attributive Спасова рука has transformed into a double personym (agionym) CnacaВарука. Perhaps the reason for that was the association with the name Варук / Варука 'Varyuha (Varvara)', which complements Причистую владыку.

Another reason for such a rethinking could be a change in the rhythmical structure of the incantation, in which the Russian word рука gained stress on the first syllable $P y K A$. In particular, this is evidenced by the emergence of the adaptation containing the plural form РуКИ:

Христос во всем скӧт и двор, благодатнӧй дом, круглӧй во дворы, крепкой стын, железной стын, неотданнӧй ворота; от зелли до небеса спасовая руки, Пречистая зальти, Христос печать. (Nalimov 1908: 1110)

This prayer, said when closing the gates, was recorded by V.P. Nalimov on the lower banks of the Sysola River at the beginning of the twentieth century. Unfortunately, this was a handwritten note, too, and its rhythmical structure cannot be reproduced. However, judging by the previous formula, the ending was the following: СПаСОВАЯ РуКИ, ПРЕЧиСТАЯ ЗаМЫТИ, ХРИСТОС ПеЧАТЬ.

We can mark the aspects that are of the utmost importance within the context of this research:

- The attributive Спасова рука, in view of its semantic ambiguity and obscurity for the Komi performers, has increased variation;

- In all of the adaptations that were considered, the word РУК $a$ was transformed into a trochee $(P y K A / P y K И)$; 
- In addition to that, the component CПаСОВA РуКA / CПаСA-ВАРyКA

/ СПаСОВАЯ РуКИ is a suitable 'blank' for the dactylic dimeter with a pyrrhic, i.e., for the rhythmical structure of the incantation.

Using the above-mentioned aspects as a basis, I propose the following adaptation of the non-linear transformation:

\section{СПа COBA РуKa}

\section{ПоД ЗАБОР уПАЛ}

Since the incantation under consideration, being a distinct spoken form, could be characterized by intonational and articulatory emphasis, a number of phonetic changes can be related to the peculiarities of this verbal-magical register:

- As a result of articulatory emphasis, the fricative $/ \mathrm{v} /$ turned into a voiced hard consonant /b/: СПаСОВA > СПаСОБА;

- As a result of articulatory emphasis, the voiceless /S/ became a voiced /Z/: СПаСОВА > СПаЗОБА; in addition to that, the vocalization of consonants (intervocal and the ones at the beginning of a word) is typical of the KomiZyrian language. The incipit of the Komi wedding lamentation ' Пазда да Причистая' (< Spas da Prichistaja) $)^{3}$ is cited as another adaptation of the vocalization.

- Assimilation of consonants: CПаСOBA РyКA > СПаСABA - РyПA;

- Prosodic shifts caused by etymological associations СПаЗАБА РуПА > (С)Па ЗАБА-Р уПА(Л).

Apparently a number of other consistent phonetic changes could be pointed out in addition to what has been mentioned already. However, the aspects described above are sufficient for imagining the overall order of the reconstruction.

СПаСОВА РуКА > СПаСАВА - РУПА > Па - САВАР - уПА(Л $>$ Па ЗАБАР уПА(Л) > Па(Д) ЗАБАР уПАЛ > ПоД ЗАБОР уПАЛ

Moreover, there could also be involved an intermediate link accomplishing the sound-and-meaning function, i.e., the borrowed word завор 'a taken-down picket fence', 'the gate in the fence for passing through' < Russian 'village gate, fence, hedge, picket fence' (Lytkin \& Gulyaev 1999: 104); it was recorded in all of the dialects of the Komi language and, apparently, was borrowed quite early, which is why the etymologization of a nonsemantic савор into завор (and later on into забор) was something that could be expected.

I do not have a stable formula or a microtext containing the attributive Спасова рука at my disposal, which is why I am not able to do the positional analysis that would be similar to the one done with relation to the Holy Son. Without any doubt, in the hypothetical prototext, the collocation Спасова рука 
occupied a very strong position, which was reinforced by syllabic and rhythmical means $(\mathbf{v}-\mathbf{- v}-)$.

\section{Preliminary conclusions}

As a result of the reconstruction that was suggested, I was able to detect possible sources of microtext 2 . As a result, the prototext of the incantation under consideration attained a certain lexical and semantic interpretation, typical of incantatory texts. The formulas of 'In the name of...' and 'Spasova ruka...' are contained in the examples I have provided as illustrative material, while the incantation against the evil еуе-волидз with the incipit Спаса-Варука can basically be accepted as an adaptation of the source I have been looking for. Let us have a look at the first part now that there is a number of specific perceptions of the possible content of the prototext.

\section{Microtext 1}

$$
\begin{aligned}
& \text { КуРИЛА МуРА } \\
& \text { ПРоКӦ ЕРМиЛА }
\end{aligned}
$$

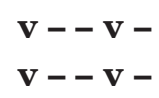

This part of the incantation has a much deeper degree of the semantic ambiguity and, possibly, also some morphological inconsistencies (taking into consideration the existing anthroponyms ПРоКӦ 'Procopius' < ?; ЕРМиЛА 'Yermil' $<$ ? (or 'Yermil Prokopyevich'), which is a result of spontaneous etymological attractions. Any attempts of finding the traces of a prototext in them (? < впрок/ проговорила/, etc.) would carry little conviction. This is why I am going to select another strategy and try to get deeper into the formal organization of this microtext.

The first two lines of the incantation are identical in terms of metrics (dactylic dimeter with a pyrrhic), but at the same time, they are opposed to each other with regard to a number of other parameters. First of all, an apparent morphological mirror-effect of the two lines should be pointed out (if we regard the word ерлила as a verb with ambiguous semantics, the mirror-effect would be syntactic, too): a trisyllabic verb + a disyllabic noun // a disyllabic noun + a trisyllabic noun / quasi verb. This principle of mirror symmetry can also be observed at the phono-rhythmical level: 


\section{Mirror symmetry}

$$
\begin{gathered}
\text { КуРИЛА МуРА } \\
3+2 \\
\text { КР }- \text { МР } \\
\text { РИЛА }- \text { M-P }
\end{gathered}
$$

\begin{tabular}{|c|c|}
\hline : & ПРоКӦ ЕРМиЛА \\
\hline :: & $2+3$ \\
\hline & $P K-P M$ \\
\hline & ПР - РМИЛА \\
\hline
\end{tabular}

We can see that a clear mirror-like structure is inherent in microtext 1 , which is why it is absolutely logical to assume that it overlaps with the sound-figurative plan. The phono-semantic analysis, in its current interpretation, is worth separate research (see Mikhalev 2009), and in order to avoid getting stuck in this topic, let us address the existing insights and practices related to it. Since the sequence of sounds in microtext 1 correlates with the overall sound-rhythmical structure of the text one way or another, let us select the sounds with the highest frequency and correlate them with the data concerning universal phonosemantic types (Mikhalev 1995: 86ff.). This is how the frequency cross-section will look: vowel phonemes [U] -3 stressed, [O] -2 stressed +4 unstressed; consonants: [B/P] -4 ; [R] -5 ; [L] - 3; concords: [RL-ML-PL], [KR-MR-PR-JR$\mathrm{BR}$, [RLMR], [JRML].

\section{Possible meanings of phonemes}

\begin{tabular}{|c|c|c|c|}
\hline Phonemes & $\begin{array}{c}\text { Onomatopoeic } \\
\text { meanings }\end{array}$ & $\begin{array}{c}\text { Articulatory- } \\
\text { symbolical } \\
\text { meanings }\end{array}$ & $\begin{array}{c}\text { Synaesthetic } \\
\text { development }\end{array}$ \\
\hline$[\mathrm{O} / \mathrm{U}]$ & howling sounds & round, deep & heavy, dark \\
\hline$[\mathrm{B} / \mathrm{P}]$ & $\begin{array}{c}\text { explosive, } \\
\text { whipping, } \\
\text { gurgling sounds }\end{array}$ & $\begin{array}{c}\text { a stroke, } \\
\text { dimensional, } \\
\text { bloated }\end{array}$ & round, full, vast \\
\hline$[\mathrm{R}]$ & $\begin{array}{c}\text { long trembling } \\
\text { sounds }\end{array}$ & $\begin{array}{c}\text { revolution, } \\
\text { repetitiveness, } \\
\text { tension }\end{array}$ & $\begin{array}{c}\text { round, any kind of } \\
\text { motion in general }\end{array}$ \\
\hline$[\mathrm{L}]$ & long trembling & $\begin{array}{c}\text { lapping up, licking, } \\
\text { liquid }\end{array}$ & pouring \\
\hline
\end{tabular}

Phonemes [U] and [O] occur nine times in the text; five of them are stressed: labial - 'roundness'; the sound is at the back, far (deep) from the entrance 'deep'. The notions of heavy and dark result from the synesthesia with the deep. 
Labial plosives [B/P] occur four times: labialness refers to the notion of roundness (especially in combination with labial vowels); the explosive nature of consonants is perfectly delivered by the onomatopoeic meaning of an explosion, while pushing the lips from each other reminds of a whip; gurgling or boiling can be a variation of the explosion, while puffing out your cheeks before letting the air out can symbolize something that is dimensional, bloated. It should be pointed out here that these sound-figurative parameters could also provoke the transition from $P y K A$ to $P y \Pi A$ and later on to $y \Pi A Л$, reconstructed above.

Vibrant $[R]$ occurs five times: the depiction of long trembling sounds (continuants) is inherent in extremely extensive onomatopoeic resources; the oscillating moves of a tongue symbolize trembling, oscillation; one of the main features of the oscillatory process is a repeated resetting into the initial position, i.e., repetitiveness, coming back, which has been one of the symbolic functions of $[R]$; on the other hand, trembling recalls rolling your tongue against the palate, hence the option of designating a rotating, circular motion and also something round as well as any kind of motion in general; vigorous articulation of the sound with the feature of tension.

Lateral $[\mathrm{L}]$ occurs three times: it is related to the 'liquid' on the basis of the specific motion of the language as an organ of licking and lapping up; in its turn, 'liquid' provides room for symbolizing against such features as pouring, smooth, even, sleek, sticky, slippery, light, etc.

Therefore, the phono-semantic specifications listed above can be joined into a common sound-symbolical image of a circular motion, the rotation of the liquid. And this image matches both the actional level and the metrical and rhythmical structure of the incantation very precisely.

\section{HYPOTHESIS FOR THE GENERATION OF INCANTATORY TEXTS}

The incantatory text has a strictly formalized rhythmical structure. Quantitative and qualitative parameters of this structure are determined by it, and have the harmonious centre and the borders that are consistent with the HC. This is why it is more appropriate to talk not about the structure, but the existence of a specific rhythmical matrix. It is this matrix that is reproduced at different levels of the organization of a word text (sound-rhythmical, syllabic-rhythmical, metrical-rhythmical, etc.) and at the actional level of the incantatory act.

The components of an incantatory prototext, which I have reconstructed, provide evidence of the non-linear nature of its transformation into the final 
text. One part of the incantation (microtext 2) is a combination of the components of the formulas 'In the name of the Father and the Son and the Holy Spirit' and 'Spasova ruka', and it was verified both lexically and syntactically as a sentence originating from the Russian language. The second part of the incantation is a microtext with the deformed lexical and semantic structure (morphological zaum), which is also verified as originating from the Russian language. It seems to be impossible to detect the original components of the source. Within the overall rhythmical matrix, this part correlates all of the levels considered above, except for the lexical-syntactic one. At the phono-semantic level, both parts of the incantation are united by common sound-symbolical meanings, which were generalized into the image of 'a circular motion, the rotation of liquid'; this image matches the actional level of the magical ritual and the rhythmical matrix on the whole.

The lack of semantic coherence with such a rigid formal organization of the text allows to claim with considerable confidence that, basically, there could be no intermediate adaptations between the source of the borrowing (prototext) and the end result. The text would lose its coherence and integrity and fall apart with even the slightest deviation from the matrix. This is why we should be dealing with a one-step, one-time transformation of the prototext into the text that we have at hand. This hypothesis is supported by another important parameter, which is the volume of the incantatory text ( 8 words) that matches the volume of a one-time perception of it (see detailed information in Rabinovich 2010). $7 \pm 2$ of the object is the capacity of a one-time perception of consciousness, the width of the information corridor, or the average capacity of short-term memory of an adult (short-term memory is the memory that is capable of storing information within 25-30 seconds after the cessation of the process of its perception). In linguistics, this capacity is called the Magical Number Seven, Plus or Minus Two, and it determined the maximum number of words in an oral sentence that can be comprehended: when we are listening to someone's speech, we have to lay the words in our heads into a single whole in order to make sense. The number of the chunks within that outlay ranges from 5 to 9 . Only after processing as many units as that, our brain moves on to comprehending the next sentence.

In terms of a one-time effect, the most likely communicative situation here would be a teacher-student scenario: the teacher is reproducing the incantatory act with a prototext, while the student, in view of certain precepts, conceives not the text itself, but some deeper levels of this magical and ritual performative. These levels are clearly related to the rhythmical matrix that I have reconstructed. Some of the parameters of this matrix have not been taken into consideration, since they are unavailable (the rhythmo-melodics of speech, the 
peculiarities of the articulation of sounds, the involvement of the representational stream and media, etc.) In order to achieve the communicative goal, the student must most probably be able to enter (or they are induced by the teacher) into a specific psychophysiological state (altered state of consciousness, perhaps, caused by psychotechnical means), which should activate cognitive processes in the situations when someone is under pressure. At first, the student conceives the rhythm of the incantation, which synchronizes the speech and the actions of the teacher; then the rhythmical matrix 'comes together' in their consciousness, into which the verbal stream is incorporated, and which has been assembled from the components of the source text, 'snatched' by the short-term memory of the student. Apparently the incantation said by the teacher is conceived as a dynamic single whole, from which the matching elements that are either harmonious or resonant with the matrix are singled out. Thus the component that lies at the $\mathrm{HC}$ of the prayer formula 'In the name of...' is incorporated into the HC of the matrix; apparently a certain 'resonating' attribute (in addition to the metrical-rhythmical match) was also inherent in the formula Спасова рука. It can be assumed that the word text is structured from the bottom to the top, i.e., from sound-rhythmical associations to syllabic-rhythmical, morphemerhythmical (morphological similarities are assembled from syllabic-rhythmical associations), lexical-rhythmical (lexical similarities are assembled from morphological matches), and further on to lexical-syntactic. The first part of the text 'freezes' at the level before last, turning into a morphological zaum. It means that once again zaum or beyonsense results from the compression of word material into a rhythmical structure, and, in theory, a new text could correspond to the dominant norms of cohesion and integrity completely.

\section{CONCLUSION}

Apparently this non-linear way of adopting the incantation does not accord with commonly used perceptions of the direct teaching of verbal knowledge and can be interpreted as a special esoteric way of initiation. It is not a mere coincidence that there are typologically close cognitive adaptations of the description of the process of transfer of magical knowledge among the perceptions popular in the Komi folklore, for instance: "Нилкьıв-incantation is transferred, but the last word is not said. And every time it gets shorter and shorter. I don't know, I guess you have to find the word yourself" (Panyukov \& Savel'yeva 1999: 60). Besides, the hypothesis agrees with the facts of the existence of the above-verbal strategic level of incantatory knowledge, which were studied by Adonyeva: 
Competence manifests itself not in the knowledge of ritual texts, but in fluency pertaining to mastering various magical strategies, the fluency that enables you to generate magical utterances of your own, by means of incorporating some additional codes which change the shape of the signs used while performing magical acts. (Adonyeva 2004: 123)

The communicative act I have considered above records the birth of a new verbal and magical register, a new incantation-нилкыв, which matches the psychophysiological parameters of a person being initiated and, apparently, their bioenergy, in view of the initial conditions of 'initiation'.

\section{NOTES}

1 Recorded by Sofia Popova in June 1935. No passport data (National Museum of the Komi Republic: KP-12481. Komi folklore collected by students of the pedagogical college in 1932-1935, p. 143).

${ }^{2}$ With respect to the stress, we are talking about the rhythmical structure of a word, which manifests itself in the text as a specific level of its rhythmo-melodics: "The "lexical" rhythm can be regarded as some kind of prosodic foundation, on top of which the rhythms of higher levels "build up", which are related to syntagmas and sentences' (Kasevich \& Yagunova 2003: 19).

${ }^{3}$ Recorded by E. Osipova from V.P. Larukova, born in the village of Nivsher in Kortkerossky District, Komi Republic, in 1935. Manuscript (National Museum of the Komi Republic: KP-12480. Komi folklore collected by students of the pedagogical college in 1930-1936, p. 37overleaf).

\section{REFERENCES}

Adonyeva 2004 = Adon'eva, Svetlana. Pragmatika fol'klora. [Folklore Pragmatics.] St. Petersburg: Izdatel'stvo Sankt-Peterburgskogo universiteta.

Davydov, Danila 2007. K probleme semantizatsii tekstual'nogo statusa: iz zametok o poeticheskoi zaumi. [To the Problem of Semantization of the Textual Status: From Notes about Poetic Zaum.] In: N. Andreeva \& N. Litvinenko \& N. Pakhsar'ian (eds.) Literatura XX veka: itogi $i$ perspektivy izucheniia. Materialy Piatykh Andreevskikh chtenii: Sbornik nauchnykh statei. Moscow: Ekon-inform, pp. 66-72.

Janecek, Gerald 1996. Zaum: The Transrational Poetry of Russian Futurism. San Diego: San Diego State University Press.

Kasevich \& Yagunova 2003 = Kasevich, Vadim \& Iagunova, Elena. Udarenie i foneticheskoe slovo v russkom iazyke. [Accent and Phonetic Word in Russian.] In: Tamara Erofeeva (ed.) Problemy sotsio- $i$ psikholingvistiki, Vyp. 3. Perm': Permskii universitet, pp. 19-25. Available at http://psychsocling.narod.ru/ kasevich_jagunova.htm, last accessed on 30 May 2019. 
Korbut, Aleksandra 2005. Tekstosimmetrika kak razdel obshchei teorii teksta. [Text Symmetrics as a Section of the General Theory of the Text.] Avtoreferat dissertatsii na soiskanie uchenoi stepeni doktora filologicheskikh nauk. Barnaul: Altaiskii Gosudarstvennyi universitet. Available at http://www.dslib.net/jazyko-znanie/ tekstosimmetrika-kak-razdel-obwej-teorii-teksta.html, last accessed on 30 May 2019.

Lytkin \& Gulyaev 1999 = Lytkin, Vasilii \& Guliaev, Evgenii. Kratkii etimologicheskii slovar' komi iazyka. [The Concise Etymological Dictionary of the Komi Language.] Syktyvkar: Komi knizhnoe izdatel'stvo.

Mikhalev, Andrei 1995. Teoriia fonosemanticheskogo polia. [Theory of the Phonosemantic Field.] Piatigorsk: Izdatel'stvo PGLU. Available at http://liconism.ru/bibliotekalibrary/298, last accessed on 30 May 2019.

Mikhalev, Andrei 2009. Sovremennoe sostoianie fonosemantiki. [The Current State of Phonosemantics.] Novye idei v lingvistike XXI veka. Materialy 1 Mezhdunarodnoi nauchnoi konferentsii, posviashchennoi pamiati professora V. A. Khomiakova. Vol. 1. Pyatigorsk: n.p., pp. 52-59.

Moskalchuk, Galina 1998. Dinamika formy teksta. [Dynamics of the Text Form.] Iazykovaia kartina mira: lingvisticheskii i kul'turologicheskii aspekty. Vol. 2. Biysk: Biiskii Gosudarstvennyi pedagogicheskii institut, pp. 22-26.

Moskalchuk, Galina 2003. Struktura teksta kak sinergeticheskii protsess. [Structure of the Text as a Synergetic Process.] Moscow: URSS.

Nalimov, Vasily 1908. Kansatieteellisiä kirjoituksia ja muistiinpanoja syrjääneistä: Venäjäksi. Suomalais-Ugrilaisen Seuran Arkisto, I. 39. Helsinki.

Panyukov 2010 = Paniukov, Anatolii. $K$ voprosu o samoorganizatsii zaumi (na materiale komi schitalok). [To the Question of Self-Organization of the Zaum (on the Material of the Komi Counting Rhymes).] Vestnik Cheliabinskogo gosudarstvennogo universiteta, No. 34 (215). Filologiia. Iskusstvovedenie. Vyp. 49, pp. 93-98.

Panyukov \& Savel'yeva 1999 = Paniukov, Anatolii \& Savel'eva, Galina (comps.) Traditsionnaia kul'tura komi: Etnografiia detstva. [Traditional Culture of the Komi: Childhood Ethnography.] Materialy fol'klorno-etnograficheskikh ekspeditsii 1995-1998 gg. Syktyvkar: Gosudarstvennyi tsentr narodnogo tvorchestva Ministerstva kul'tury Respubliki Komi.

Rabinovich, Mikhail 2010. Operativnaia pamiat' i chislo sem'. [Operative Memory and the Number Seven.] Nauka i zhizn', No. 8. Available at http://www.nkj.ru/archive/ articles/18456/, last accessed on 30 May 2019.

Shlyakhova 2006 = Shliakhova, Svetlana. Fonosemanticheskie marginalii v russkoi rechi . [Phonosemantic Marginalias in the Russian Speech.] Avtoreferat dissertatsii na soiskanie uchenoi stepeni doktora filologicheskikh nauk. Perm': Permskii Gosudarstvennyi pedagogicheskii universitet. Available at http://liconism.ru/ biblioteka-library/254, last accessed on 30 May 2019.

Sidorov, Aleksei 1997 [1928]. Znakharstvo, koldovstvo i porcha u narodov komi. Materialy po psikhologii koldovstva. [Folk Healing, Magic and Witchcraft among the Komi People: Materials of the Psychology of Magic.] St. Petersburg: Aleteiia.

Ulyashev 1999 = Uliashev, Oleg. Nimkyv. [Incantation.] In: Anna-Leena Siikala \& Vladimir Napol'skih \& Mihály Hoppál (eds.) Entsiklopediia ural'skikh mifologii. T. I. Mifologiia komi. Moscow \& Syktyvkar: DIK, pp. 256-258. Available at https:// www.academia.edu/8463469/, last accessed on 30 May 2019. 
Vinogradova, Liudmila 2002. Ta voda, kotoraia... (Priznaki, opredeliaiushchie magicheskie svoistva vody). [The Water That... (The Signs Defining Magic Properties of Water).] In: Svetlana Tolstaia (ed.) Priznakovoe prostranstvo kul'tury. Moscow: Indrik, pp. 32-60. Available at https://inslav.ru/images/stories/pdf/2002_Priznakovoe_ prostranstvo_kultury.pdf, last accessed on 30 May 2019. 